\title{
A simple technique to study embodied language processes: the grip force sensor
}

\author{
Tatjana A. Nazir ${ }^{1}$ - Lianna Hrycyk ${ }^{1}$ - Quentin Moreau ${ }^{1}$ - Victor Frak ${ }^{2}$ • Anne Cheylus ${ }^{1}$. \\ Laurent $\mathrm{Ott}^{3}$ • Oliver Lindemann ${ }^{4}$ • Martin H. Fischer ${ }^{4}$ - Yves Paulignan ${ }^{1}$. \\ Yvonne Delevoye-Turrell ${ }^{3}$
}

Published online: 24 December 2015

(C) Psychonomic Society, Inc. 2015

\begin{abstract}
Research in cognitive neuroscience has shown that brain structures serving perceptual, emotional, and motor processes are also recruited during the understanding of language when it refers to emotion, perception, and action. However, the exact linguistic and extralinguistic conditions under which such language-induced activity in modality-specific cortex is triggered are not yet well understood. The purpose of this study is to introduce a simple experimental technique that allows for the online measure of language-induced activity in motor structures of the brain. This technique consists in the use of a grip force sensor that captures subtle grip force variations while participants listen to words and sentences. Since grip force reflects activity in motor brain structures, the continuous monitoring of force fluctuations provides a fine-grained estimation of motor activity across time. In other terms, this method allows for both localization of the source of language-induced activity to motor brain structures and high temporal resolution of the recorded data. To facilitate comparison of the data to be collected with this tool, we present two experiments that describe in detail the technical setup, the nature of the recorded data, and the analyses (including justification about the data filtering and artifact rejection) that we
\end{abstract}

Tatjana A. Nazir

tatjana.nazir@isc.cnrs.fr

1 1L2C2 Institut des Sciences Cognitives-Marc Jeannerod, CNRS/ UCBL, Université Claude Bernard Lyon 1, Bron, France

2 Département de Kinanthropologie, Faculté des Sciences, Université du Québec à Montréal, Montréal, Canada

3 Laboratoire URECA, UDL3, Université Lille Nord de France, Lille, France

4 Department Psychologie, Universität Potsdam, Potsdam, Germany applied. We also discuss how the tool could be used in other domains of behavioral research.

Keywords Grip-force sensor · Embodiment $\cdot$ Language . Motor system

In a landmark demonstration, Hauk, Johnsrude, and Pulvermüller (2004) showed that the passive processing of isolated words denoting motor actions activates brain structures involved in the planning and execution of those voluntary movements. Similar observations in other modalities (e.g., words denoting color activate the fusiform gyrus just anterior to color-selective regions of extrastriate visual cortex, and words denoting odor activate olfactory areas in the prepiriform cortex; see Binder \& Desai, 2011, for a review) have had a tremendous impact on our understanding of the neural basis of lexical meaning. As a matter of fact, the activation of modality-specific brain structures by language was perceived as evidence that these structures participate in the elaboration of word semantics. However, as experimentations became more sophisticated and words were presented within sentences, the picture became more complex. For example, language-induced activity in modality-specific brain structures varies with the linguistic and extralinguistic context (e.g., Willems \& Casasanto, 2011). Hence, whereas the word "to push" in a sentence such as "Now I push the button" triggers activity in the brain's motor structures, little evidence for such activity is obtained for the same action word when it is presented in a negative context (e.g., "Now I do not push the button"; e.g., Tettamanti et al., 2008; see also Aravena et al., 2012). Moody and Gennari (2010) also showed that the effort implied by a given action word modulates activity in premotor cortex. Hence, the word "to push" triggers more activity in motor structures when it is presented in a sentence such as "The delivery man is pushing the 
piano," rather than a sentence such as "The delivery man is pushing the chair." Similarly, van Elk, van Schie, Zwaan, and Bekkering (2010) reported differential neural responses for the word "swim" when the action was performed by an animal or by a human ("The duck swims in the pond" vs. "The woman swims in the pond"). The flexibility with which modalityspecific brain regions are recruited by language remains consistent with the view that cerebral motor structures contribute to the elaboration of meaning. Nonetheless, such flexibility suggests that this recruitment might not be a function of the (literal) word meaning, but rather of the (implied) speaker meaning. In other terms, the recruitment of these structures hinges on principles of inference (cf. pragmatics) and depends on the utterance context and preexisting knowledge. In order to understand the role of modality-specific brain structures in meaning construction, the specification of conditions under which these structures are recruited by language becomes necessary. For such a purpose, experimental tools that allow the rapid and economical testing of hypotheses would be of major help. Here, we describe in detail a simple experimental tool - a grip force sensor - to capture online the involvement of motor structures in the processing of language that describes motor actions (Aravena et al., 2014; Aravena et al., 2012; Frak, Nazir, Goyette, Cohen, and Jeannerod 2010).

Our ability to hold and lift objects depends critically on successful predictive and reactive control of the grip forces required to prevent the slippage of these objects through our finger tips (Delevoye-Turrell \& Wing, 2005). We must sense various object characteristics, such as their weight, surface structure, and shape. This information is transferred from primary, premotor, supplementary, and cingulate cortical motor areas via spinal motor neurons into the finger muscles (e.g., Dum \& Strick, 1991; Lemon, 1993). Kuhtz-Buschbeck, Ehrsson, and Forssberg (2001) used MRI to show that the automatic adjustments of grip force during normal holding of an object are controlled via the (contralateral) primary sensorimotor cortex and the (contralateral) intraparietal cortex. When participants intentionally increase their grip force to hold the object more firmly, dorsal and ventral premotor cortices are also involved. The continuous control of grip force is thus well understood in terms of its neurophysiological regulation, and the usefulness of grip force assessment in clinical diagnosis and pediatrics has long been established (e.g., Delevoye-Turrell, Giersch, \& Danion, 2003; Nowak \& Hermsdörfer, 2006; Rauch et al., 2002). By monitoring grip force in healthy individuals, our team recently revealed that subtle but selective grip force variations could be seen during the processing of language that refers to motor actions (Aravena et al., 2014; Aravena et al., 2012; Frak et al., 2010). In these studies, participants listened to individual spoken words or sentences while holding a grip force sensor that continuously monitored grip force variations throughout the experiment. Their task was simply to count the occurrence of a predefined target within the sentence- - for example, the number of times the name of a country was mentioned within the verbal material. These studies revealed that when the sentence contained an action word - but not otherwise - a significant enhancement of the grip force level was observed starting within the first $300 \mathrm{~ms}$ after action-word onset. Modulations of the sentential context further specified that an increase in grip force to action words hinged on the relevance of the action within the verbally described situation. More specifically, grip force to action words increased when the word was presented within an affirmative sentential context ("Fiona signs the contract"), but not when it was presented within either a negative context ("Fiona does not sign the contract") or a volitional context ("Fiona wants to sign the contract") (Aravena et al., 2014; Aravena et al., 2012).

The work by Frak et al. (2010) and Aravena et al. (2014; Aravena et al., 2012) pioneered the use of the grip force sensor for studies on language processing. However, because of yet missing standards, the way data were recorded and analyzed changed from one study to another. Today, our experience with this tool has accumulated, and we here aim to suggest criteria for the use of the sensor in order to facilitate the comparison of data collected with this tool. In the following text, we thus present two experiments that describe in detail the technical setup, as well as the nature of the recorded data and the analyses that were applied. One important observation that we made over past experiments is that without an explicit instruction about the initial strength of grip force that participants should apply on the sensor, some participants tend to hold the sensor too loosely. The data from these participants tend to remain close to zero, independently of experimental conditions. In the present study, we thus explicitly instructed participants to voluntarily apply a constant force on the sensor. Since psycholinguistic studies typically span dozens of minutes, in the first experiment we simply monitored the fluctuations in grip force level over time when the participant was not involved in any specific task. This experiment allowed for the determination of when pauses should be introduced into an experimental design in order to limit motor and/or cognitive fatigue. The second experiment reports the specific effects observed on the variations in grip force levels when processing language materials related to motor actions. This experiment serves to explain the different criteria that we chose for data filtering and artifact rejection.

\section{Experiment 1}

\section{Method}

Ethics statement All participants in this study gave their informed written consent. The study was approved by the ethics 
committee, Comité de Protection des Personnes Sud-Est II, in Lyon, France (IRB 11263).

Participants A total of 16 participants with no reported history of psychiatric or neurological disorders participated in the experiment. They were all right-handed (i.e., they used their right hand for at least seven of the ten actions described in the Edinburgh Handedness Inventory; Oldfield, 1971) and had no prior knowledge about the scientific aim of the study.

Equipment and data acquisition Two distinct computers were used for data recording and stimulus presentation, in order to ensure synchronization between the audio files and grip force measurements (estimated error $<5 \mathrm{~ms}$ ). These error estimations were computed by comparing the time interval between the triggers that were received before and after reading a .wav file and the actual .wav file duration. Note that these error variations are very small even if they are associated with the sum of the delays between the sound card iterations and other real-time processes that occasionally occur on Windows operating systems.

The first computer was used to send an initial trigger through the parallel port and a terminal trigger after 241, $000 \mathrm{~ms}$ (corresponding to the total duration of a trial). The second computer thus received two triggers from the first computer, indicating the beginning and the end of the period of interest during which data were to be acquired. The second computer also recorded the incoming force signals from the load cell at a high sampling rate of $1 \mathrm{kHz}$ through an analogdigital converter card. To measure the activity of the hand muscles, a standalone six-axis load cell weighing $68 \mathrm{~g}$ was used (ATI Industrial Automation, USA, www.ati-ia.com/ Products/ft/sensors.aspx; see Fig. 1). Force torques were also recorded, but these are not reported.

Procedure Participants were comfortably seated at a desk. They were asked to rest their right arm on the tabletop and to hold the load cell between the thumb, index, and middle fingers of their right hand. The hand posture was controlled so as to have the wrist slightly tilted upward, to avoid resting the load cell on the tabletop. The experimenter demonstrated the desired arm and hand positions, and participants were asked to hold the cell with a constant grip force of $1.5 \mathrm{~N}$. To achieve this, at the start of the experiment the experimenter instructed participants to increase their grip force until the level of $1.5 \mathrm{~N}$ was reached. Participants were then requested to maintain this grip force for a total of $4 \mathrm{~min}$, during which no further feedback was given. Participants closed their eyes throughout the duration of the experiment.

Data analysis Only the compression force, Fz, was included in the analysis, because this parameter is the most accurate indicator of prehensile grip force (Frak et al., 2010). It captures the force vector perpendicular to the contacted surfaces of the sensor.

\section{Results and discussion}

Figure 2a plots the untransformed raw data to show individual variations in grip force amplitude over the 4-min period (240, $000 \mathrm{~ms}$ ) for each of the 16 participants. ${ }^{1}$ Figure $2 \mathrm{~b}$ plots the average of these data from all participants, indicating an initial force of 1,537.68 $\mathrm{mN}$ and a final force of $1,251.34 \mathrm{mN}$, equivalent to an $18.62 \%$ drop in mean grip force across the recording period.

In the absence of slippage, grip force is controlled via proprioception solely when participants are required to close their eyes. Under such conditions, a systematic reduction in grip force levels was observed over the course of the 4-min trial. Similar results have been reported in other domains of postural control. They most likely reflect the gradual loss of propriceptive sensitivity. For example, Wann and Ibrahim (1992) found systematic drift of perceived limb position toward the body during visual occlusion unless occasional glimpses of the arm were provided. The authors therefore concluded that visual updating is important to prevent proprioceptive drift (PD). Nevertheless, Wolpert, Goodbody, and Husain (1998) and Desmurget, Vindras, Gréa, Viviani, and Grafton (2000) found only limited PD even in the absence of visual information in situations in which an object was held in a precision grip for intervals of under a minute.

In the present study, we will show that grip force gradually drifts over extended periods of time. Despite the fact that the average grip force level at the beginning of the experiment is set at $1.5 \mathrm{~N}$, our data showed a large variation between participants' performance right from the start of the experiment. This may be explained by the fact that the preset $1.5-\mathrm{N}$ force level was above the slip-ratio limit, which can be estimated to be close to $27 \mathrm{~g}$ (i.e., $27 \mathrm{mN}$ ) when holding an object of $68 \mathrm{~g}$ (Turrell, Li, \& Wing, 2001). Hence, even if participants lowered their grip force level during the trial, the level was never low enough to risk object slippage. To note, all participants revealed a clear drop in grip force level over the $4 \mathrm{~min}$, suggesting that frequent breaks followed by a recalibration of the grip force should be considered. Most importantly, some participants (e.g., Participants 5 and 9) exhibited particularly strong cyclical modulations of grip force as compared to the others. Figure 2 allows a visualization of these different points while providing the means of identifying these participants who were prone to noisy data (i.e., voluntary grip force modulations), despite the absence of a particular task to perform. These participants could bias the results of language experiments, especially if the number of trials per condition was small. As we will see in Experiment 2, these participants can

\footnotetext{
${ }^{1}$ Note the presence of $1 / f$ fluctuations in the data, which could bear complementary information not exploited currently.
} 


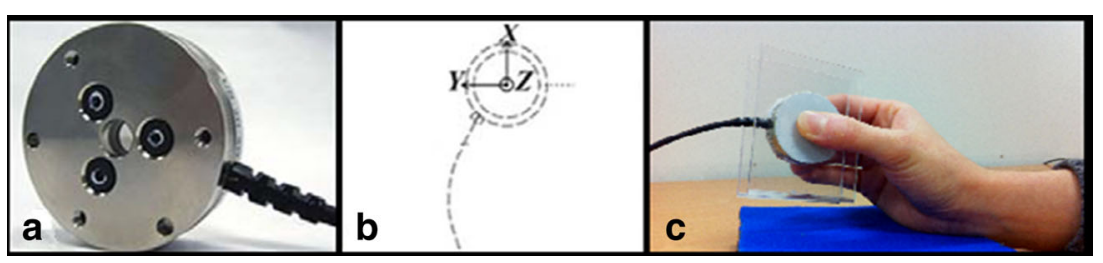

Fig. 1 Experimental material and setting. a A standalone six-axis load cell of $68 \mathrm{~g}$ was used (ATI Industrial Automation, USA). b The three main forces were recorded: Fx, Fy, and Fz, as the longitudinal, radial, and compression forces, respectively. $\mathbf{c}$ Participants hold the grip force sensor

and should be discarded with an automatic artifact rejection procedure.

\section{Experiment 2}

\section{Method}

Participants A total of 26 (15 females, 11 males) right-handed French students (mean age $=21.2$ years old, $S D=2.27$ ) with no known hearing problems or reported history of psychiatric or neurological disorders participated in the experiment. Sixteen of these participants had also participated in Experiment 1.

Stimuli A total of 115 French sentences were binaurally presented to each participant. Thirty-five target action words were embedded once within action-in-focus sentences (e.g., "Paul signe le formulaire": "Paul signs the form") and once within subject-in-focus sentences (e.g., "C'est Paul qui signe le contrat": "It is Paul who signs the contract"). For the present purpose, the subject-in-focus condition is not relevant because it concerns a linguistically oriented issue related to the "The Question Under Discussion" debate in language processing. These data have no immediate methodological bearing, but their theoretical implications will be reported elsewhere. All target action words were verbs denoting actions performed with the hand or arm (e.g., "scratch" or "throw") and were in the third-person present tense. Verbs always occurred in the same position in the sentence. To avoid repeating the same sentence in the two focus conditions, two equivalent lists of 70 sentences with different protagonists' names were generated for the target words. Hence, in the action-in-focus condition the verb "to sign" was embedded in the sentence "Paul signs the form" in List 1, and in "Carlos signs the contract" in List 2. An additional 35 control sentences containing nonaction verbs (e.g., to dream, to hesitate) were included in each list as a baseline. The action verbs and the nonaction verbs were controlled for frequency, number of syllables, and number of letters (see Appendix B). Finally, ten sentences containing the name of a country were added, serving as target sentences, which required participants to increment their mental counter of such events. An example of the stimuli used in each condition is given in Table 1 (see Appendix A for all of the stimuli). Six versions of in a precision grip with their right hand. Participants wore headphones and were comfortably seated behind a desk on which a pad was placed. They were asked to rest their arms on the pad, holding the sensor

each list, with a different pseudorandomized distribution of sentence types, were generated and were alternated between participants.

The voice of a French female adult was recorded while she read the sentences, using Adobe Soundbooth. The mean word durations were $330 \mathrm{~ms}$ $(S D=8.67 \mathrm{~ms})$ for the action verbs and $408 \mathrm{~ms}$ ( $S D$ $=7.55 \mathrm{~ms}$ ) for the nonaction verbs. There was a pause of $2,000 \mathrm{~ms}$ between the presentations of the sentences.

Equipment and data acquisition These were identical to those aspects of Experiment 1.

Procedure Participants wore headphones and were comfortably seated at a desk. They were asked to rest their right arm on the tabletop. Participants were required to hold the load cell as described in Experiment 1 and were guided through feedback from the experimenter to increase grip force until it reached the level of $1.5 \mathrm{~N}$. Participants had their eyes closed throughout the duration of the experiment. They were instructed to carefully listen to the sentences and to silently count the total number of sentences that contained the name of a country. To avoid muscular fatigue, participants were given a break after every 20 sentences (approximately every $80 \mathrm{~s}$ ). During this break, they were requested to rest the cell on the table while they rotated and relaxed their hand as they pleased, until they were ready to continue. After the rest periods, the initial grip force calibration of $1.5 \mathrm{~N}$ was again applied. The entire experiment lasted approximately 7-9 $\mathrm{min}$, depending on the length of time each participant took during the five breaks.

Data analysis Prior to the data analysis, each signal component was low-pass filtered at $15 \mathrm{~Hz}$ with a fourth-order, zerophase, low-pass Butterworth filter. The Fz signal was then segmented into 1,000-ms epochs, spanning from $200 \mathrm{~ms}$ prior to the target word onset to $800 \mathrm{~ms}$ after target word onset. A baseline correction was performed on the mean amplitude of the interval spanning from 200 to $0 \mathrm{~ms}$ prior to target word onset. The baseline correction was implemented because of a possible global change in grip force during the session, and because we were only interested in grip force changes. Thus, we adjusted the poststimulus values by the values present 

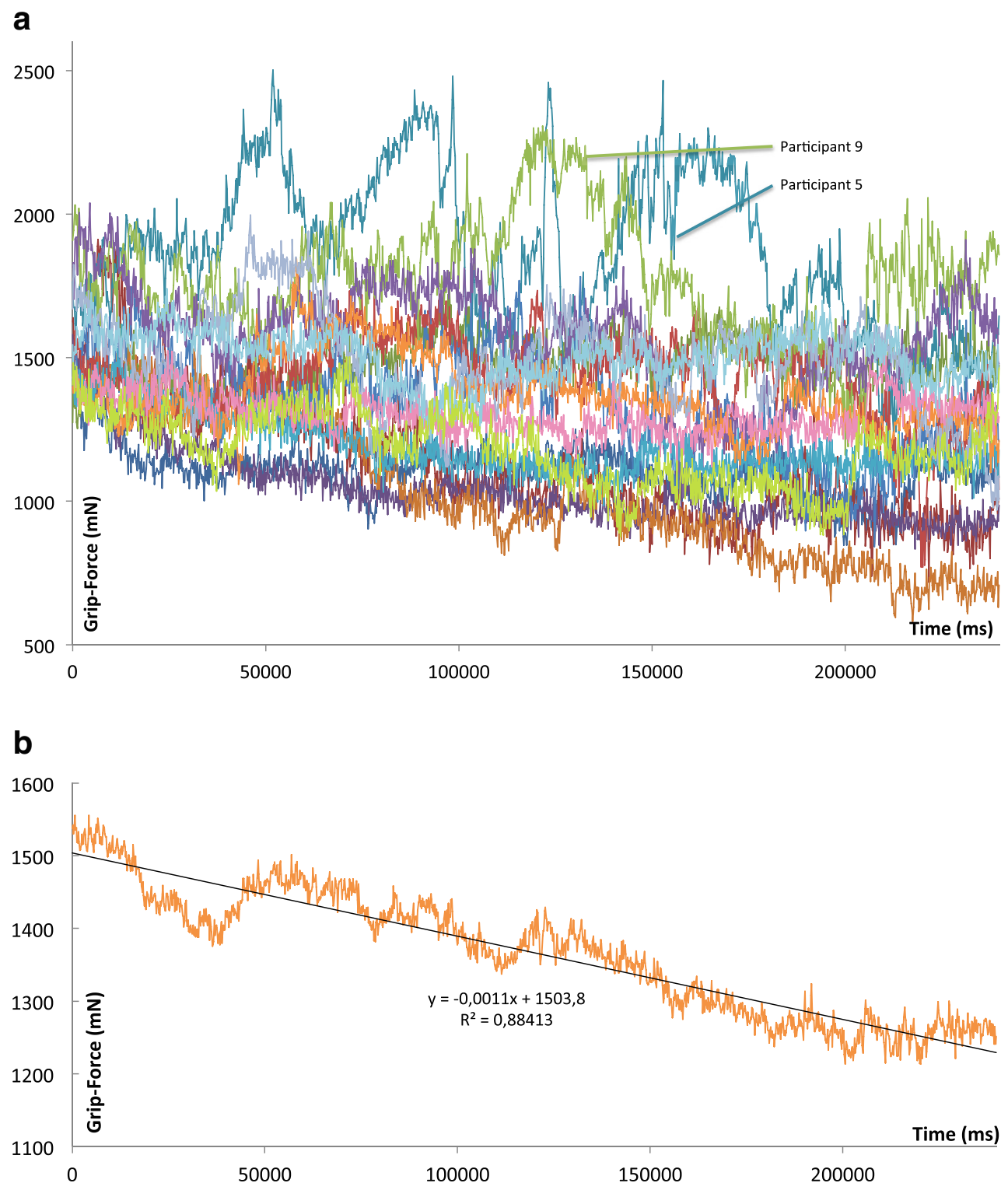

Fig. 2 a Hand fatigue and trembling tendencies in healthy participant while holding the load cell for $4 \mathrm{~min}$. Individual data from 16 participants, which are coded by color. b Average hand fatigue and slackening while

holding the load cell for $4 \mathrm{~min}$ : Comparison of data averaged over all 16 participants

during the baseline period. A simple subtraction of the baseline values from all of the values in the epoch for each given trial was performed. Since the participants were asked to hold the grip force sensor throughout the experiment, a "negative" grip force will refer to a decrease in grip force with respect to the baseline (and not to the absence of grip force, which would imply dropping the sensor cell). Finally, an automatic artifact rejection was used to remove segments surpassing an amplitude range of $\pm 200 \mathrm{mN}$ with respect to the baseline and/or showing an amplitude change of more than $100 \mathrm{mN}$ within a

Table 1 Examples of stimuli used in Experiment 2 and their approximate English translation

\begin{tabular}{lll}
\hline Type of Stimuli & Sentence & Approximate English Translation \\
\hline Action-in-focus & Jacques brosse ses dents. & Jacques brushes his teeth. \\
Control sentences with nonaction verbs & Lyse tente de compléter son devoir. & Lyse attempts to complete her homework. \\
Target sentences containing the name of a country & Caroline planifie une excursion en Italie. & Caroline plans an excursion in Italy. \\
\hline
\end{tabular}

Underlined words represent the target words, and bolded words represent the linguistic focus of the sentence 
period of less than $100 \mathrm{~ms}$, which is indicative of finger movements. Participants with an artifact rejection rate of more than $20 \%$ per condition (i.e., more than $7 / 35$ segments) were excluded from the analyses. The Fz signals for action words in the action-in-focus condition were averaged for each participant, as were those for nonaction words in the control condition. Justifications for these criteria are given in the "Results and discussion" section.

Following Aravena et al. (2014; Aravena et al., 2012), to evaluate the time course of language-induced motor activation, we drew on an influential neurophysiological model of spoken sentence comprehension by Friederici (2002). According to this model, information about syntactic structure is formed in a first phase on the basis of information about word category approximately $100-300 \mathrm{~ms}$ after word onset. In a second phase (300-500 ms), lexical-semantic and morphosyntactic processes are computed for thematic role assignments. In a third and final phase $(500-1,000 \mathrm{~ms})$, the information that was generated in Phases 1 and 2 is integrated and reanalyzed. Applying this model, for each word condition (action verbs and nonaction verbs), the averaged grip force values in the three time windows were compared with the proper baseline (i.e., the averaged grip force values over the segment between -200 and $0 \mathrm{~ms}$ before word onset). For the windows that presented significant grip force modulations with respect to that baseline, a comparison between the conditions was conducted using repeated measures analysis of variance (ANOVA).

\section{Results and discussion}

Individual data To illustrate the different steps of our data analyses, we will first present the data from two typical participants, one whose data are representative (Participant 19) and another whose data are too noisy to exploit correctly (Participant 5). Note that Participant 5 also had noisy data in Experiment 1, indicating the presence of idiosyncratic grip force signatures.

Filter Figure 3 plots the fast Fourier transforms (FFT) performed on the raw data of each participant (calculated over the entire signal from the start to the end of the experiment), which served to identify the frequency range with significant information. As is evident from this figure, which is highly representative of all included participants, little information is contained beyond $15 \mathrm{~Hz}$. Note also the peak at $50 \mathrm{~Hz}$, due to electrical power lines. Given this pattern, we suggest filtering the continuous grip force data at $15 \mathrm{~Hz}$.

Artifact rejection Figure 4 plots the signal after segmentation ( $-200 \mathrm{~ms}$ prior to word onset to $800 \mathrm{~ms}$ poststimulus) and baseline corrections in the condition that contained an action verb $(N=35$ segments). Once data were corrected for the baseline, we applied an automatic artifact rejection algorithm using the following criteria:

a) Amplitude: Trials in which the amplitude exceeded $\pm 200 \mathrm{mN}$ compared to baseline. The choice of this criterion was based on visual inspection of our data, and might serve as a general guideline when an initial grip force level of $1.5 \mathrm{~N}$ was applied. Rejecting these trials thus discarded outliers relative to the initial grip force, as well as identified participants that showed strong fluctuations in grip force levels.

b) Max-Min (x): Trials that contained a sudden change in force amplitude of more than $100 \mathrm{mN}$ within an interval of $100 \mathrm{~ms}$. This criterion discarded trials in which participants moved their fingers.

The multicolored segments in the figure (left panels) represent trials that were rejected when we applied our artifact rejection criteria. For Participant 19, the three rejected trials showed sudden changes in grip force levels that were likely due to finger movements. A total of $32 / 35$ segments (91.43\% of data) were retained and served for calculating the individual means. For Participant 5, by contrast, strong grip force fluctuations were observed both between and within segments. For this participant, 22 of the 35 trials were automatically rejected by our artifact rejection procedure, leaving a total of only 13 trials - that is, $37.14 \%$ were acceptable segments. Consequently, the data from Participant 5 were excluded from further analyses. Note that our choice to eliminate participants with more than $20 \%$ rejected trials (i.e., $n=7$ ), related to the limited number of trials per condition. With decreasing numbers of trials, single outliers can have an important impact on the mean. The central panels of Fig. 4 plot trials that survived the automatic artifact rejection, whereas the right panel shows the average of these remaining trials plotted with the standard error of the mean $(S E M)$. Note that through the averaging procedure, the contribution of extreme values is attenuated (i.e., the resulting signal fluctuates around the middle of the dispersion of most signals). Note also the different scales used for the mean individual averages.

Group means The data of 21 participants who passed the artifact rejection procedure were then averaged as a function of the experimental conditions. Figure 5 shows the averaged variation in grip force as a function of time after onset of the action verb and the nonaction verb, respectively. The SEMs are illustrated as colored shadows around the individual lines on the graph. As can be seen in this figure, the grip forces remained comparable and close to baseline for both conditions prior to word onset at $t=0 \mathrm{~ms}$. For the action-in-focus condition, a steady increase in grip force (the compression force component of the load cell, Fz) was subsequently observed, 

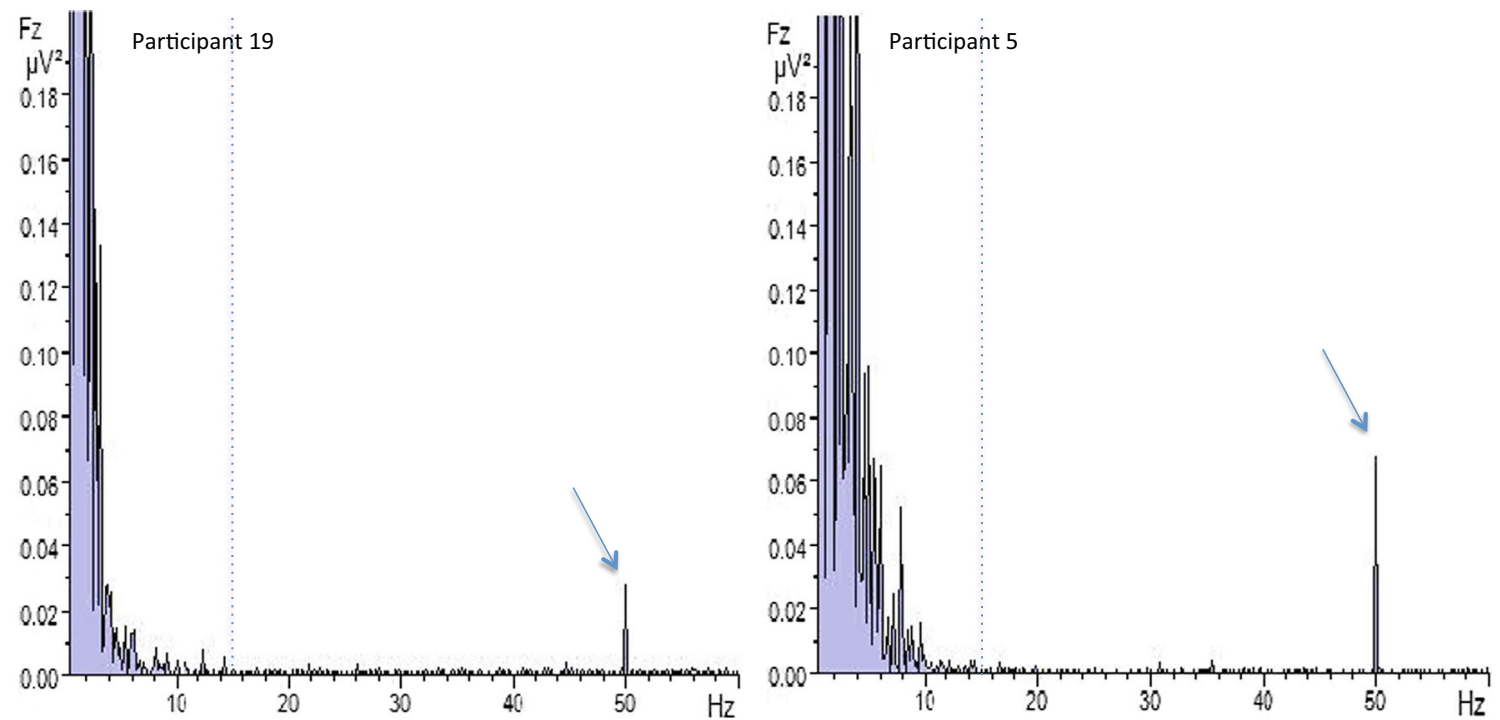

Fig. 3 Fast Fourier transform (FFT) for Participants 19 (left) and 5 (right.) Little information is contained beyond $15 \mathrm{~Hz}$ (dotted vertical lines). The arrows point to $50-\mathrm{Hz}$ signals that are due to electrical power lines

which continued to increase until the end of the recorded segment. By contrast, in the nonaction verb condition, the averaged grip force remained nearly constant at baseline. For the action-in-focus condition, the ANOVA revealed a significant difference in force amplitude relative to that observed in the baseline phase, and this was observed in all three time windows $[F(1,20)=36.28, p<.0001 ; F(1,20)=31.45, p<$ .0001 ; and $F(1,20)=20.03, p=.0002$, for the first, second, and third windows, respectively]. In the nonaction verb condition, grip force did not differ significantly from baseline in
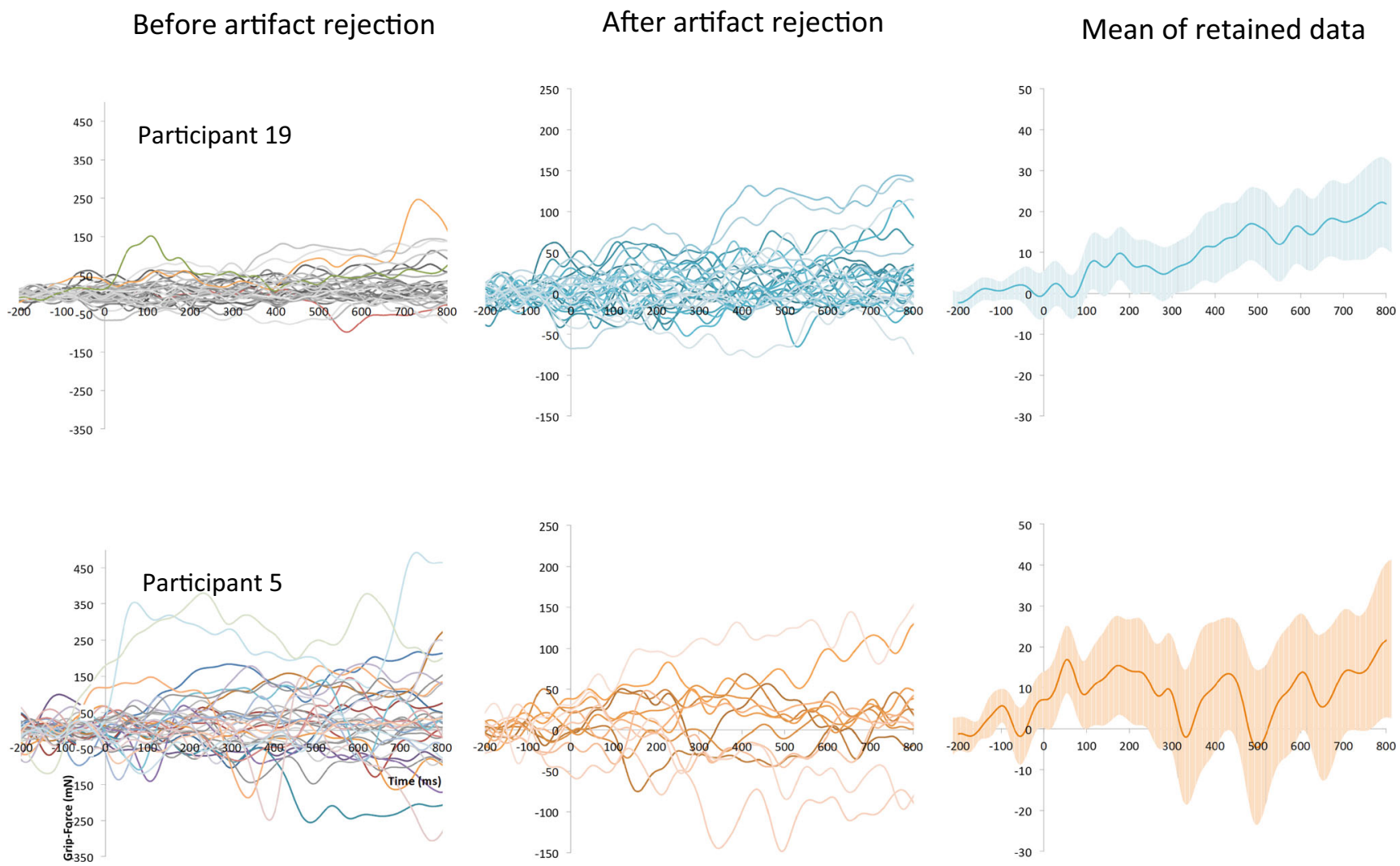

Fig. 4 Data from Participants 19 (top) and 5 (bottom.) The left panels display all 35 segments. Colored segments did not survive the artifact rejection. The central panels plot the remaining trials after artifact

rejection, and the right panels show the means over the remaining trials (plotted with SEM) 


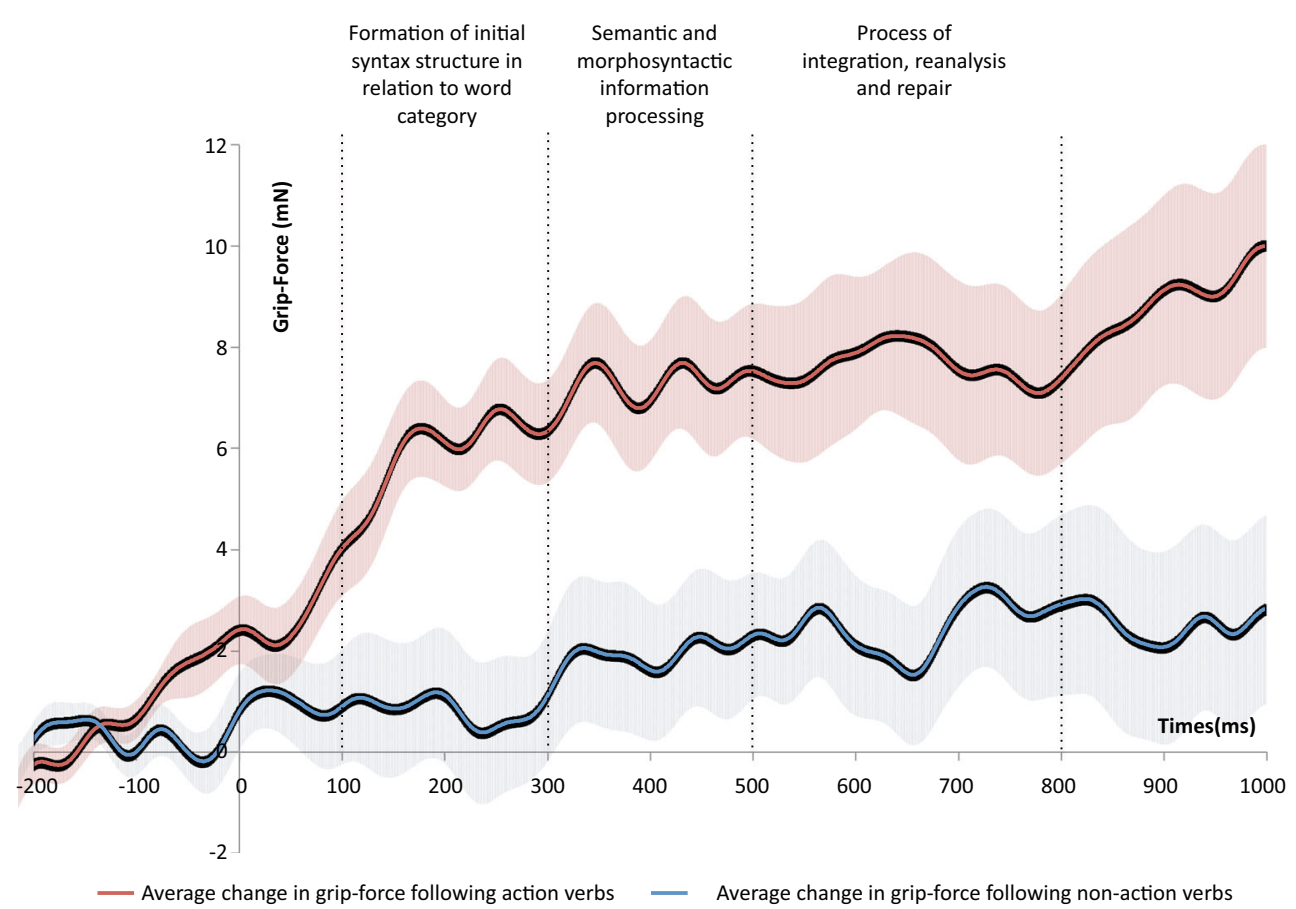

Fig. 5 Modulation of grip force amplitude as a function of the time after target onset, with a $15-\mathrm{Hz}$ low-pass filter: Comparison of data averaged over all participants. Word onset occurs at $t=0 \mathrm{~ms}$. The standard error
$(S E M)$ is illustrated as a colored shadow around the individual lines on the graph. The time windows of interest (100-300, 300-500, and 500 $800 \mathrm{~ms}$ ) are marked by dotted lines any of the three windows. A contrast between the action-infocus condition versus the nonaction control condition also revealed significant differences in all time windows $[F(1$, $20)=10.038, p=.0048 ; F(1,20)=9.37, p=.0062 ;$ and $F(1,20)=7.663, p=.0119$, for the first, second, and third windows, respectively].

As a note of caution, Fig. 6 plots the data of each of the 21 participants ( $x$-axis) in the action-in-focus (blue diamonds) and the nonaction (red circles) conditions. For each participant the data are averaged over all trials and over the entire window in the three intervals of interest (i.e., 100-300, 300-500, and 500-800 ms). The first 13 participants also took part in Experiment 1, and the last eight performed Experiment 2 only. Although a direct comparison of the two groups did not reveal statistically significant differences between the groups, it is interesting to note that several participants from the first group show enhanced grip force levels in the nonaction condition. This pattern is not as evident in the second group. Performing several experiments with the same participants might thus potentially weaken the experimental effect.

In line with our previous findings (Aravena et al., 2012; Aravena et al., 2014; Frak et al., 2010), the present results confirm that the processing of action words within a sentential context focused on body action provokes a sustained increase in grip force levels starting within the first 300 -ms period after word onset - that is, within the time frames associated in the model proposed by Friederici (2002) with the retrieval of word form and word category. Note that the rather early onset of these effects is in line with studies in which event-related potentials have been analyzed during spoken sentence processing. These studies have shown that listeners rapidly relate the acoustic signal to the semantic context before they even know what the unfolding word is going to be (for a review, see Hagoort, 2008). In addition, the present work has identified important sources of artifacts and clarified how to deal with them in future work.

\section{General discussion}

The two experiments presented here serve to demonstrate how fine-grained analyses of grip force fluctuations can reveal language-induced activity originating from the motor structures of the brain. When variables related to gradual force drifts (proprioceptive drift-see Exp. 1) and noise (due to abrupt finger movements or psychological factors such as fatigue - see Exps. 1 and 2) are controlled for, the measures obtained from a grip force sensor reveal an increase in muscle activity within a few hundred milliseconds after the onset of an action word. Note that, given the conduction time of approximately $18-20 \mathrm{~ms}$ between the primary motor cortex (M1) and hand muscles (estimations using transcranial magnetic stimulation; Rossini, Rossi, Pasqualetti, \& Tecchio, 1999), activity in cortical motor structures occurs slightly earlier than that measured on the sensor. Thus, simply subtracting this value from the onset of significant force modulations provides a good 


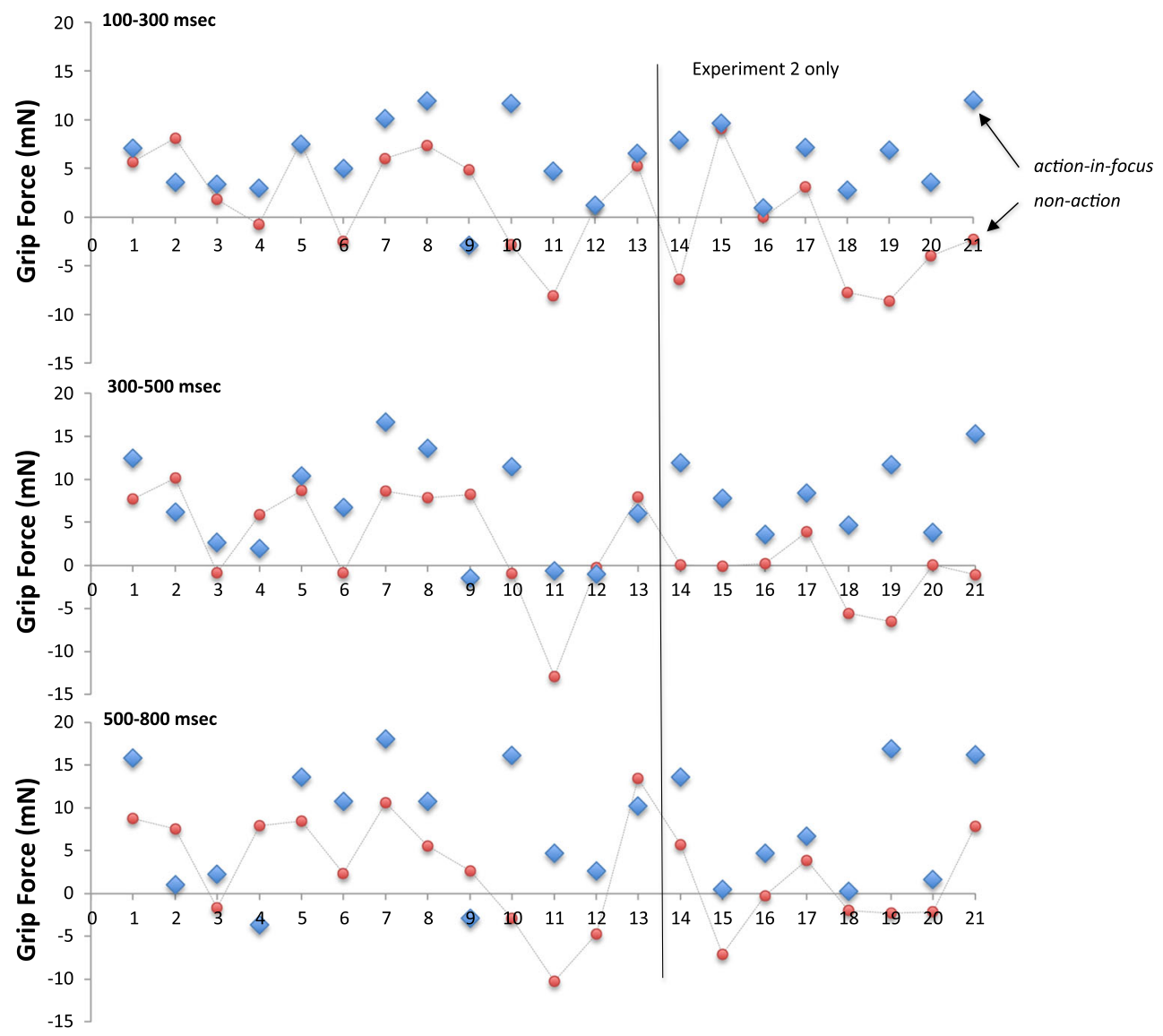

Fig. 6 Individual data of the 21 participants ( $x$-axis) in the action-infocus (blue diamonds) and the nonaction (red circles) conditions. For each participant the data are averaged over all trials and over the entire

estimation of the onset of brain activity in these motor structures. The majority of corticospinal projections originate from M1, although dorsal and ventral premotor areas, cingulate motor areas, and supplementary motor area contribute to the corticospinal projection, as well (see Maier et al., 2002). Brain imaging is thus necessary for determining where within those motor structures the observed language effects occur.

In conclusion, through the fine-grained analysis of grip force variations during language processing, it is possible to obtain a valid and sensitive method to rapidly test hypotheses about the potential involvement of motor brain structures in language processing. Subsequent verification with brain-imaging methods could help confirm these assumptions. A clear limitation of the present method is that testing is currently limited to action words, whereas research on embodied language processing focuses on language-induced activity in all modalityspecific brain structures. Note, however, that by implementing a strip-force transducer, we could easily measure the force output modulations of other body parts (leg, mouth, or body). Similarly, although until now we have used the device to investigate the perception of language understanding, it could equally well serve studies on language production. window in the three intervals of interest (i.e., 100-300, 300-500, and 500-800 ms.) The first 13 participants also took part in Experiment 1, and the last eight participants performed Experiment 2 only

The grip force paradigm can also help us gain a better understanding of the properties of motor simulation - that is, the cognitive processes that are involved in (1) the preparation of voluntary actions and (2) the anticipation of the effects of an action, as well as (3) the understanding of the intention of an action performed by others. Motor simulation studies have used subjective verbal reports or brain-imaging techniques because an efficient behavioral approach was lacking. We suggest that our passive grip force paradigm could serve as an objective tool to study the dynamics of motor simulation across many fields of cognitive sciences. In line with this suggestion, we recently used our paradigm to reveal the motor simulation processes that take place while watching videos of action scenes in an odorant-augmented environment (Blampain \& Delevoye-Turrell, 2015). Finally, because the passive grip force paradigm requires no specific body position or movement, it may provide great potential for investigating the neural correlates of motor simulation using electroencephalography and Nirs technologies (see, e.g., Krause, Lindemann, Toni, \& Bekkering, 2014), and it could also serve studies on motor system pathologies. 
The motor system is the only way the human brain can communicate. We thus proposed here that the use of grip force sensors can be a powerful tool to gain a better understanding of how the motor system intervenes for embodied social communication, in both verbal and gestural contexts.

Author note This research was supported by the French National Center for Scientific Research (CNRS).

\section{Appendix A}

\section{Table 2 Lists of sentences}

Condition 1: Action-in-focus sentences with action verbs $(35 \times 2$ sentences containing the same action word)

1. Etienne se rase la barbe. (Etienne shaves his beard.)

2. Julia se rase les jambes. (Julia shaves her legs.)

3. Bastien jette le papier dans la poubelle. (Bastien throws the paper in the trash.)

4. William jette sa pomme dans le seau. (William throws his apple into the bucket.)

5. Adela tord la serviette qui est tombé dans l'eau. (Adela wrings out the towel that fell into the water.)

6. Marc tord le torchon mouillé par la pluie. (Marc twists the towel that was wet by the rain)

7. Abby racle le fond de son assiette. (Abby scrapes the bottom of his plate.)

8. Claire racle le fond de la casserole. (Claire scrapes the bottom of the pan.)

9. Anna serre le boulon sur son vélo. (Anna tightens the bolt of her bike.)

10. Camille serre le nœud de ses chaussures. (Camille tightens the knot of her shoes.)

11. Carlos signe le contrat. (Carlos signs the contract.)

12. Paul signe le formulaire. (Paul signs the form.)

13. Danielle vernit la table. (Danielle varnishes the table.)

14. Thomas vernit le meuble ancien. (Thomas varnishes the antique furniture.)

15. David agite la main pour saluer. (David waves his hand to greet.)

16. Diane agite le drapeau pour appeler à l'aide. (Diane waves the flag to call for help.)

17. Elena épile les jambes de sa cliente. (Elena depilates the legs of her client.)

18. Emma s'épile les jambes pour l'été. (Emma depilates her legs in summer.)

19. Fanny enfouit les objets précieux. (Fanny buries the valuables objects.)

20. Laure enfouit son trésor au fond du jardin. (Laure buries his treasure in the garden.)

21. Gabriel frappe à la porte. (Gabriel knocks at the door.)

22. Louis frappe sur le clou. (Louis hits the nail.)

23. James jongle avec les oranges. (James juggles with oranges.)

24. Jeanne jongle avec quatre balles. (Jeanne juggles with four balls.)

25. Mathilde peigne ses longs cheveux. (Mathilde combs her long hair.)
Table 2 (continued)

26. Lise peigne les cheveux de sa Barbie. (Lise combs the hair of her Barbie doll.)

27. Anne secoue la bouteille de jus. (Anne shakes the juice bottle.)

28. Julie secoue les ingrédients pour préparer un cocktail.

29. Karine balaye le trottoir. (Karine sweeps the sidewalk.)

30. Bruno balaye le plancher. (Bruno sweeps the floor.)

31. Laura soulève son bagage. (Laura lifts her luggage.)

32. Maude soulève sa tasse. (Maude lifts her cup.)

33. Madeleine astique le dos de la casserole. (Madeleine polishes the back of the pan.)

34. Marie astique le coffre de sa grand-mère. (Marie polishes the trunk of her grandmother)

35. Stéphane colorie les dessins. (Stéphane colors the drawings.)

36. Yann colorie les œufs de Pâques. (Yann paints the Easter eggs.)

37. Rémi dessine le contour des fleurs. (Rémi draws the contours of the flowers.)

38. Brice dessine un volcan en éruption. (Brice draws an erupting volcano.)

39. Patrick pianote sur le volant. (Patrick taps on the steering wheel.)

40. Nina pianote sur la table. (Nina taps on the table.)

41. Pauline savonne les cheveux de son enfant. (Pauline lathers her child's hair.)

42. Steve savonne les poils de son chien. (Steve lathers the hair of his dog.)

43. Sabine tricote une écharpe. (Sabine knits a scarf.)

44. Sandra tricote les mitaines. (Sandra knits mittens.)

45. Vincent arrose les plantes. (Vincent waters the plants.)

46.Viviane arrose ses tulipes. (Viviane waters her tulips.)

47. Anne tape une lettre de motivation. (Anne types a letter of motivation.)

48. Juliette tape un courriel. (Juliette types an email.)

49. Maël déchire l'enveloppe de la lettre reçue. (Maël tore the envelope of the received letter.)

50. Henri déchire l'emballage du cadeau. (Henri tore off the packaging of the gift.)

51. Max appuie sur le bouton rouge. (Max presses the red button.)

52. Morgane appuie sur l'agrafeuse. (Morgan presses on the stapler.)

53. Jade aplatit la pâte à tarte. (Jade flatten the pie dough.)

54. Jérémie aplatit la pâte à modeler. (Jeremiah flattened the modeling pastes.)

55. Sonia découpe des personnages en papier. (Sonia cuts out paper figures.)

56. Émilie découpe des bons de réduction. (Emilia cuts coupons.)

57. Ginette verse de l'eau dans les verres. (Ginette pours water into the glasses.)

58. Yves verse le café dans la tasse. (Yves pours the coffee into the cup.) 59. Alex pince le bras de son camarade. (Alex pinches the arm of his friend.)

60. Max pince la jambe à sa sœur. (Max pinches his sister's leg.)

61. Jacques ouvre le placard. (Jacques opens the closet.)

62. Samantha ouvre la porte. (Samantha opens the door.)

63. Sam fauche le blé. (Sam mows the wheat.)

64. Elisa fauche les grandes herbes. (Elisa mows the tall grasses.)

65. Jackie montre le chemin à prendre. (Jackie indicates the way to go.)

66. Joseph montre les montagnes. (Joseph indicates/shows the mountains.)

67. Jacques brosse ses dents. (Jacques brushes his teeth.)

68. Samantha brosse son chat. (Samantha brushes her cat.)

69. Jackie râpe le fromage. (Jackie grates the cheese.)

70. Joseph râpe les carottes. (Jackie grates the cheese carrots.)

Control condition: Sentences with nonaction verbs

1. Lucas décide de se promener dans la campagne. (Lucas decides to go for a walk in the countryside.) 
Table 2 (continued)

2. Irène s'apprête à se regarder dans le miroir. (Irène is about to look into the mirror.)

3. Jade répugne à céder aux caprices de son fils. (Jade is reluctant to give in to the whims of her son.)

4. Laure conçoit d'oublier le travail. (Laure decides to forget about work.)

5. Brice choisit de rester au lit. (Brice chose to stay in bed.)

6. Bruno hésite à acheter des carottes. (Bruno hesitates to buy carrots.)

7. Paul se résigne à entrer chez lui bredouille. (Paul resigns to go home empty-handed.)

8. Claire rêve de faire le tour du monde. (Claire dreams to travel around the world.)

9. Lyse tente de compléter son devoir. (Lyse tries to complete her homework.)

10. Alex songe à changer de profession. (Alex thinks of changing profession.)

11. Marie désire raconter sa journée. (Mary whishes to tell her day.)

12. Anna observe travailler les étudiants.( Anna observes the students working.)

13. Jeanne opte pour demander une augmentation. (Jeanne chooses to ask for a raise.)

14. Jean prédit échouer son examen. (Jean predicts that he will fail his exams.)

15. Henri juge nécessaire de s'évader de son quotidien. (Henri deems necessary to escape from his everyday life.)

16. Yann cherche à suivre une formation d'ingénieur. (Yann seeks to train as an engineer.)

17. Julia admet de rêvasser toute la journée. (Julia admits to daydream all day.)

18. Alain estime pouvoir bien réussir son examen. (Alain expects to do well in his exams.)

19. Christophe affirme de savoir bien nager. (Christophe affirms to be able to swim well.)

20. Jérôme approuve de se reposer le matin. (Jerome agrees to get a rest in the morning.)

21. Jérémie assume de faire son défi. (Jeremiah takes to make the challenge.)

22. Sam aspire à devenir médecin. (Sam aspires to become a doctor.)

23. Julien avise d'acheter une voiture économique. (Julien advises buying an economy car.)

24. Pam doute de réussir son projet. (Pam doubt her capacity to succeed the project.)

25. Luc devine être coupable de la bêtise. (Luke guesses being guilty of the stupidity.)

26. Camille stipule d'ajouter une dernière condition. (Camille says to add one final condition.)

27. Eléonore emploie pour travailler un nouveau stagiaire. (Eleanor hires for work a new trainee.)

28. Emma constate de travailler très tard. (Emma acknowledges to work very late.)

29. Jordan admire de pouvoir gravir l'Everest. (Jordan admire to be able to climb the Everest.)

30. Lois subis de devoir travailler plus. (Lois endures to have to work longer.)

31. Gwladys ose dire son opinion. (Gwladys dare saying her opinion.)

32. Sarah se défit de surmonter cette épreuve. (Sarah challenges to overcome the ordeal.)

33. Marine tolère de rester dans la voiture. (Marine accepts to stay in the car.)

34. Elena risque d'avoir un accident. (Elena risks to have an accident.)

35. Luc jure de dire la vérité. (Luke swears to tell the truth.)

Distractor sentences containing the name of a country

1. Yannick voyage au Japon. (Yannick travels to Japan.)

2. C'est Anne qui visite le Canada. (It is Anne who visits Canada.)

3. Caroline planifie une excursion en Italie. (Caroline plans a trip to Italy.)
Table 2 (continued)

4. C'est Samantha qui prévoit rentrer en Espagne. (It is Samantha who plans to return to Spain.)

5. Gabriel navigue sur le Nil en Égypte. (Gabriel sails on the Nile in Egypt.)

6. C'est Hélène qui escalade les montagnes en Suisse. (It is Helen who climbs the mountains in Switzerland.)

7. Peter sillonne l'Australie. (Peter crosses Australia.)

8. C'est Alissa qui se promène le long de la muraille de Chine. (It is Alissa who walks along the Great Wall of China.)

9. Laurent annonce qu'il part pour le Congo. (Laurent announces that he leaves for Congo.)

10. C'est Sarah qui quitte sa maison en Allemagne. (It is Sarah who quits his home in Germany.)

\section{Appendix B}

Table 3 Target word statistics

\begin{tabular}{|c|c|c|c|c|}
\hline & Syllables & Letters & $\begin{array}{c}\text { Frequency in } \\
\text { Movies }\end{array}$ & $\begin{array}{c}\text { Frequency in } \\
\text { Books }\end{array}$ \\
\hline \multicolumn{5}{|l|}{ Action Verbs } \\
\hline raser & 2 & 5 & 28.54 & 43.78 \\
\hline montrer & 2 & 7 & 327.33 & 276.55 \\
\hline prier & 2 & 5 & 313.12 & 105.74 \\
\hline jeter & 2 & 5 & 192.18 & 336.82 \\
\hline tordre & 1 & 6 & 12.24 & 38.38 \\
\hline racler & 2 & 6 & 1.36 & 12.5 \\
\hline vernir & 2 & 6 & 1.77 & 8.51 \\
\hline pincer & 2 & 6 & 10.84 & 23.65 \\
\hline serrer & 2 & 6 & 50.99 & 207.5 \\
\hline signer & 2 & 6 & 98.19 & 55.81 \\
\hline épiler & 3 & 6 & 2.04 & 2.77 \\
\hline agiter & 3 & 6 & 14.62 & 89.19 \\
\hline ouvrir & 2 & 6 & 413.32 & 492.5 \\
\hline jongler & 2 & 7 & 2.13 & 3.85 \\
\hline peigner & 2 & 7 & 2.25 & 4.39 \\
\hline brosser & 2 & 7 & 7.65 & 10.14 \\
\hline verser & 2 & 7 & 31.2 & 53.99 \\
\hline enfouir & 2 & 7 & 4.3 & 26.76 \\
\hline aplatir & 2 & 7 & 1.91 & 14.53 \\
\hline appuyer & 3 & 7 & 40.95 & 126.01 \\
\hline taper & 2 & 5 & 61.07 & 67.91 \\
\hline secouer & 2 & 7 & 19 & 116.35 \\
\hline frapper & 2 & 7 & 160.04 & 168.31 \\
\hline râper & 2 & 5 & 1.22 & 4.46 \\
\hline balayer & 3 & 7 & 12.17 & 37.43 \\
\hline arroser & 3 & 7 & 14.07 & 19.73 \\
\hline soulever & 2 & 8 & 24.26 & 113.38 \\
\hline pianoter & 3 & 8 & 0.41 & 2.36 \\
\hline savonner & 3 & 8 & 0.79 & 4.19 \\
\hline colorier & 3 & 8 & 1.1 & 9.39 \\
\hline
\end{tabular}


Table 3 (continued)

\begin{tabular}{|c|c|c|c|c|}
\hline astiquer & 3 & 8 & 3 & 9.8 \\
\hline tricoter & 3 & 8 & 3.19 & 13.04 \\
\hline découper & 3 & 8 & 12.71 & 32.7 \\
\hline déchirer & 3 & 8 & 26.46 & 53.11 \\
\hline dessiner & 3 & 8 & 29.97 & 79.66 \\
\hline $\begin{array}{l}\text { Average (action } \\
\text { verbs) }\end{array}$ & 2.303 & 6.636 & 55.040 & 76.740 \\
\hline \multicolumn{5}{|l|}{ Nonaction Verbs } \\
\hline opter & 2 & 5 & 1.98 & 5.14 \\
\hline juger & 2 & 5 & 56.12 & 96.96 \\
\hline rêver & 2 & 5 & 122.95 & 128.18 \\
\hline songer & 2 & 6 & 24.59 & 104.86 \\
\hline tenter & 2 & 6 & 79.75 & 126.96 \\
\hline admirer & 2 & 7 & 32.39 & 68.18 \\
\hline douter & 2 & 6 & 77.77 & 88.11 \\
\hline admettre & 2 & 8 & 50.05 & 59.46 \\
\hline tolérer & 3 & 8 & 13.05 & 13.45 \\
\hline chercher & 2 & 8 & 712.46 & 448.99 \\
\hline subir & 2 & 5 & 30.13 & 53.72 \\
\hline oser & 2 & 4 & 90.2 & 155.54 \\
\hline deviner & 3 & 7 & 72.77 & 112.3 \\
\hline approuver & 3 & 9 & 15.39 & 36.08 \\
\hline aspirer & 3 & 7 & 12.07 & 28.85 \\
\hline défier & 3 & 6 & 13.49 & 12.3 \\
\hline risquer & 2 & 7 & 100.4 & 99.32 \\
\hline assumer & 3 & 7 & 12.83 & 14.8 \\
\hline aviser & 3 & 6 & 9.77 & 27.5 \\
\hline décider & 3 & 7 & 207.76 & 214.19 \\
\hline désirer & 3 & 7 & 65.63 & 61.89 \\
\hline stipuler & 3 & 8 & 1.81 & 0.54 \\
\hline hésiter & 3 & 7 & 30.06 & 122.43 \\
\hline apprêter & 3 & 8 & 9.13 & 29.46 \\
\hline constater & 3 & 9 & 10.58 & 57.43 \\
\hline observer & 3 & 8 & 42.66 & 116.01 \\
\hline jurer & 2 & 5 & 148.41 & 81.76 \\
\hline choisir & 2 & 6 & 170.48 & 133.92 \\
\hline répugner & 3 & 8 & 4.55 & 10.34 \\
\hline résigner & 3 & 8 & 3.84 & 20.34 \\
\hline prédire & 2 & 7 & 9.05 & 6.82 \\
\hline concevoir & 3 & 9 & 18.75 & 27.84 \\
\hline estimer & 3 & 7 & 21.41 & 37.64 \\
\hline affirmer & 3 & 8 & 15.61 & 63.51 \\
\hline employer & 3 & 8 & 19.47 & 46.22 \\
\hline $\begin{array}{l}\text { Average } \\
\text { (nonaction } \\
\text { verbs) }\end{array}$ & 2.571 & 6.914 & 65.925 & 77.458 \\
\hline Student's $t$ Test & $p$ Value & & & \\
\hline Syllables & .0709 & & & \\
\hline Letters & .4743 & & & \\
\hline $\begin{array}{l}\text { Frequency in } \\
\text { movies }\end{array}$ & .6893 & & & \\
\hline $\begin{array}{l}\text { Frequency in } \\
\text { books }\end{array}$ & .9544 & & & \\
\hline
\end{tabular}

\section{References}

Aravena, P., Courson, M., Frak, V., Cheylus, A., Paulignan, Y., Deprez, V., \& Nazir, T. A. (2014). Action relevance in linguistic context drives word-induced motor activity. Frontiers in Human Neuroscience, 8, 163. doi:10.3389/fnhum.2014. 00163
Aravena, P., Delevoye-Turrell, Y., Deprez, V., Cheylus, A., Paulignan, Y., Frak, V., \& Nazir, T. A. (2012). Grip force reveals the context sensitivity of language-induced motor activity during "action words" processing: Evidence from sentential negation. PLOS ONE, 7, e50287. doi:10.1371/journal. pone. 0050287

Binder, J. R., \& Desai, R. H. (2011). The neurobiology of semantic memory. Trends in Cognitive Sciences, 15, 527-536. doi:10.1016/ j.tics.2011.10.001

Blampain, J., \& Delevoye-Turrell, Y. (2015). Effect of action scenes on muscular contraction: Evidence provided by a grip-force sensor. Poster presented at the 14th European Congress of Sport Psychology, Bern, Switzerland.

Delevoye-Turrell, Y., Giersch, A., \& Danion, J. M. (2003). Abnormal sequencing of motor actions in patients with schizophrenia: Evidence from grip force adjustments during object manipulation. American Journal of Psychiatry, 160, 134-141.

Delevoye-Turrell, Y., \& Wing, A. (2005). Action and motor skills: Adaptive behaviour for intended goals. In K. Lamberts \& R. Goldstone (Eds.), Handbook of cognition (pp. 130-160). London: Sage. Retrieved from http://knowledge.sagepub.com/view/hdbk cognition/SAGE.xml

Desmurget, M., Vindras, P., Gréa, H., Viviani, P., \& Grafton, S. T. (2000). Proprioception does not quickly drift during visual occlusion. Experimental Brain Research, 134, 363-377.

Dum, R. P., \& Strick, P. L. (1991). The origin of corticospinal projections from the premotor areas in the frontal lobe. Journal of Neuroscience, 11, 667-689.

Frak, V., Nazir, T. A., Goyette, M., Cohen, H., \& Jeannerod, M. (2010). Grip force is part of the semantic representation of manual action verbs. PLoS ONE, 5, e9728. doi:10.1371/ journal.pone. 0009728

Friederici, A. D. (2002). Towards a neural basis of auditory sentence processing. Trends in Cognitive Sciences, 6, 78-84.

Hagoort, P. (2008). The fractionation of spoken language understanding by measuring electrical and magnetic brain signals. Philosophical Transactions of the Royal Society B, 363, 1055-1069. doi:10.1098/ rstb.2007.2159

Hauk, O., Johnsrude, I., \& Pulvermüller, F. (2004). Somatotopic representation of action words in human motor and premotor cortex. Neuron, 41, 301-307. doi:10.1016/s0896-6273(03)00838-9

Krause, F., Lindemann, O., Toni, I., \& Bekkering, H. (2014). Different brains process numbers differently: Structural bases of individual differences in spatial and nonspatial number representations. Journal of Cognitive Neuroscience, 26, 768-776. doi:10.1162/ jocn a 00518

Kuhtz-Buschbeck, J. P., Ehrsson, H. H., \& Forssberg, H. (2001). Human brain activity in the control of fine static precision grip forces: An fMRI study. European Journal of Neuroscience, 14, 382-390.

Lemon, R. N. (1993). Cortical control of the primate hand. Experimental Physiology, 78, 263-301.

Maier, M. A., Armand, J., Kirkwood, P. A., Yang, H. W., Davis, J. N., \& Lemon, R. N. (2002). Differences in the corticospinal projection from primary motor cortex and supplementary motor area to macaque upper limb motoneurons: An anatomical and electrophysiological study. Cerebral Cortex, 12, 281-296.

Moody, C. L., \& Gennari, S. P. (2010). Effects of implied physical effort in sensory-motor and pre-frontal cortex during language comprehension. NeuroImage, 49, 782-793.

Nowak, D. A., \& Hermsdörfer, J. (2006). Objective evaluation of manual performance deficits in neurological movement disorders. Brain Research Reviews, 51, 108-124.

Oldfield, R. C. (1971). The assessment and analysis of handedness: The Edinburgh inventory. Neuropsychologia, 9, 97-113. doi:10.1016/ 0028-3932(71)90067-4 
Rauch, F., Neu, C. M., Wassmer, G., Beck, B., Rieger-Wettengl, G., Rietschel, E., ... Schoenau, E. (2002). Muscle analysis by measurement of maximal isometric grip force: New reference data and clinical applications in pediatrics. Pediatric Research, 51, 505-510.

Rossini, P. M., Rossi, S., Pasqualetti, P., \& Tecchio, F. (1999). Corticospinal excitability modulation to hand muscles during movement imagery. Cerebral Cortex, 9, 161-167. doi:10. 1093/cercor/9.2.161

Tettamanti, M., Manenti, R., Della Rosa, P. A., Falini, A., Perani, D., Cappa, S. F., \& Moro, A. (2008). Negation in the brain: Modulating action representations. NeuroImage, 43, 358-367. doi: 10.1016/j.neuroimage.2008.08.004

Turrell, Y. N., Li, F. X., \& Wing, A. M. (2001). Estimating the minimum grip force required when grasping objects under impulsive loading conditions. Behavior Research Methods, Instruments, \& Computers, 33, 38-45.

van Elk, M., van Schie, H. T., Zwaan, R. A., \& Bekkering, H. (2010). The functional role of motor activation in language processing: Motor cortical oscillations support lexical-semantic retrieval. NeuroImage, 50, 665-677. doi:10.1016/j.neuroimage.2009.12.123

Wann, J. P., \& Ibrahim, S. F. (1992). Does limb proprioception drift? Experimental Brain Research, 91, 162-166.

Willems, R. M., \& Casasanto, D. (2011). Flexibility in embodied language understanding. Frontiers in Psychology, 2, 116. doi:10. 3389/fpsyg.2011.00116

Wolpert, D. M., Goodbody, S. J., \& Husain, M. (1998). Maintaining internal representations: The role of the human superior parietal lobe. Nature Neuroscience, 1, 529-533. 